\title{
Trakeomalasia pada Anak
}

\author{
I G. A. P. Eka Pratiwi, Putu Siadi Purniti, I. B. Subanada \\ Bagian Ilmu Kesehatan Anak Fakultas Kedokteran Universitas Udayana/RS Sanglah Denpasar Bali
}

\begin{abstract}
Trakeomalasia merupakan suatu keadaan kelemahan trakea yang disebabkan karena kurang dan atau atrofi serat elastis longitudinal pars membranasea, atau gangguan integritas kartilago sehingga jalan napas menjadi lebih lemah dan mudah kolaps. Trakeomalasia pada anak dapat diklasifikasikan menjadi dua yaitu trakeomalasia primer (penyakit kongenital) dan sekunder (penyakit didapat). Untuk menegakkan diagnosis trakeomalasia dapat dilakukan dengan anamnesis, pemeriksaan fisik, dan pemeriksaan pencitraan. Manifestasi klinis trakeomalasia antara lain riwayat stridor ekspirasi, kesulitan minum, suara parau, afonia, riwayat breath holding, riwayat intubasi berkepanjangan, trakeostomi, trauma dada, trakeobronkitis berulang, penyakit kartilago (polikondritis relaps), dan reseksi paru. Sebagian besar anak dengan trakeomalasia tidak memerlukan intervensi. Terapi bedah diperlukan jika terapi konservatif tidak mencukupi atau jika terjadi refleks apne, mengalami kesulitan peningkatan berat badan dan perkembangan, mengalami pneumonia atau apne berulang, menunjukkan obstruksi jalan napas yang memerlukan dukungan jalan napas kronik. Gejala kinis akan menghilang secara spontan pada usia 18-24 bulan. (Sari Pediatri 2007; 9(4):233-8).
\end{abstract}

Kata kunci: trakeomalasia, anak

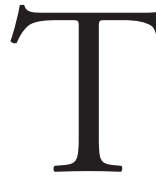

rakeomalasia merupakan keadaan kelemahan trakea yang disebabkan karena atropi dan atau berkurangnya serat elastis longitudinal pars membranasea, atau akibat gangguan integritas kartilago sehingga jalan napas menjadi lemah dan mudah kolaps, terutama saat

\footnotetext{
Alamat korespondensi

Dr. Putu Siadi Purniti, Sp.A Dr. I. B. Subanada, Sp.A Divisi Respirologi. Bag./SMF Ilmu Kesehatan Anak FK UNUD/RSUP Sanglah Denpasar Jl. Pulau Nias 80114 Telp./Fax. (0361) 244038 atau (0361) 257387 Dr I G. A. P. Eka Pratiwi PPDS Ilmu Kesehatan Anak FK UNUD, Denpasar
}

terjadi peningkatan aliran udara, misalnya saat batuk, menangis, atau menyusui. ${ }^{1,2}$ Pada trakeomalasia terjadi peregangan dinding membran posterior dan pengurangan kaliber jalan napas anterior-posterior. ${ }^{2}$ Trakeomalasia merupakan suatu kelainan kongenital atau didapat, berupa suatu kelainan tunggal atau bagian dari kelainan lain yang menyebabkan penekanan pada jalan napas. ${ }^{3,4}$ Keadaan ini ringan, dengan gejala obstruksi jalan napas, sehingga sering disalah artikan sebagai asma atau bronkiolitis berkepanjangan. ${ }^{1,3}$

Insiden trakeomalasia bentuk kongenital diperkirakan 1 per 1.445 bayi. ${ }^{5}$ Pada suatu penelitian terhadap 50 bayi dengan trakeomalasia didapatkan 
$48 \%$ merupakan trakeomalasia primer dan 52\% trakeomalasia sekunder. ${ }^{6}$ Predileksi ras dan jenis kelamin tidak ditemukan pada trakeomalasia. ${ }^{3}$ Literatur mengenai trakeomalasia sangat sedikit. Referensi yang paling awal mengenai trakeomalasia berasal dari tahun 1930-an dan 1940-an yaitu pada saat beberapa klinisi menggambarkan mengenai abnormalitas vaskular dada kongenital yang menyebabkan obstruksi trakea. ${ }^{1}$

\section{Etiopatogenesis dan Patofisiologi}

Trakeomalasia terjadi secara kongenital atau didapat. Trakeomalasia kongenital dapat berupa suatu bagian dari kelainan kongenital difus atau hanya bagian dari suatu kelainan kongenital fokal. Misalnya pada atresia esofagus dan fistula trakeoesofagus, ${ }^{1,2}$ terdapat kelainan struktur kartilago jalan napas atas terjadi menyeluruh atau fokal sebagai akibat sekunder perkembangan foregut dan vaskular masa embrional yang abnormal. ${ }^{2}$ Trakeomalasia kongenital lebih sering ditemukan pada bayi prematur daripada bayi cukup bulan. Penemuan ini mendukung pandangan bahwa salah satu penyebab trakeomalasia kongenital adalah imaturitas kartilago trakeobronkial. Penyebab lain trakeomalasia kongenital adalah formasi bahan matriks kartilago trakea yang abnormal sehingga terjadi dismaturitas serat kolagen dan kelemahan jaringan trakeobronkial. Misalnya terdapat pada polikondritis dan kondromalasia. ${ }^{1}$

Trakeomalasia sering berhubungan dengan atresia esofagus, ${ }^{7,8}$ diduga karena faktor penyebab berpengaruh pula terhadap perkembangan trakea, dan anomali pembuluh darah besar akan meningkatkan keparahan trakeomalasia. ${ }^{8}$

Trakeomalasia didapat disebabkan karena degenerasi jaringan penunjang kartilago normal oleh berbagai macam penyebab, antara lain akibat kompresi internal pipa endobronkial, trakeostomi, trakeobronkitis berat, dan penekanan struktrur abnormal paratrakea. ${ }^{1}$ Juga dapat terjadi karena reseksi paru, keganasan trakea (silindroma), atau idiopatik. ${ }^{2}$ Penyebab tersering adalah intubasi endotrakeal yang berkepanjangan, menyebabkan peningkatan tekanan jalan napas, keracunan oksigen, dan infeksi berulang, akhirnya menyebabkan degenerasi kartilago trakea. Pada trakeostomi terjadi nekrosis akibat tekanan, gangguan aliran darah, infeksi, atau kerusakan mukosa akibat gesekan yang menyebabkan proses degenerasi. Kejadian trakeomalasia didapat meningkat sesuai umur dan sering tidak terdeteksi.

Selama siklus pernapasan normal, kaliber trakea berubah karena fleksibilitas intrinsik dan kemampuan mengembang trakea. Trakea intratoraks akan berdilatasi dan memanjang saat inspirasi, menyempit dan memendek saat ekspirasi akibat dari perbedaan tekanan intratoraks dan intralumen trakea. ${ }^{1,2}$ Pada sebagian besar kasus trakeomalasia terjadi penyempitan berlebihan trakea intratoraks terutama saat tekanan intratoraks lebih besar dibanding tekanan intralumen trakea, misalnya saat ekspirasi paksa, batuk, atau manuver Valsava. Pada trakeomalasia ekstratoraks atau daerah leher, tekanan negatif intrapleura diteruskan menuju trakea ekstratoraks sehingga jalan napas atas kolaps selama inspirasi. ${ }^{1}$ Trakeomalasia ekstratoraks atau daerah leher lebih jarang terjadi (paling sering terjadi pada trakea $1 / 3$ distal). ${ }^{1,2}$

Kelainan yang paling sering terjadi pada trakeomalasia adalah malformasi cincin kartilago, menyebabkan lumen trakea menjadi oval dan tidak bulat lagi. ${ }^{9}$ Hilangnya rigiditas struktur trakea tersebut menyebabkan trakea kolaps dan terjadi peningkatan abnormal usaha pengembangan trakea. $^{2}$

\section{Klasifikasi}

Trakeomalasia pada anak diklasifikasikan menjadi 3 tipe berdasar sistem klasifikasi kolapsnya jalan nafas utama, gambaran histologi dan gambaran pada endoskopi. Tipe I menunjukkan trakea kolaps akibat abnormalitas trakea kongenital atau intrinsik, bukan akibat kompresi jalan napas dari luar trakea. Kelompok ini mencakup trakeomalasia pada bayi kurang bulan, atresia esofagus, fistula trakeoesofagus, sindrom mukopolisakarida dan sindrom Larsen. Tipe II terjadi akibat kompresi ekstrinsik yang menyebabkan trakea kolaps, misalnya akibat anomali pembuluh darah, kista, teratoma, hemangioma, pembesaran timus, atau gondok yang mengakibatkan penekanan trakea. Tipe III merupakan trakeomalasia didapat yang terjadi karena intubasi yang berkepanjangan, trakeostomi, atau trakeobronkitis berat. ${ }^{1,2}$ Trakeomalasia pada anak dapat juga diklasifikasikan menjadi dua berdasarkan penyebabnya yaitu trakeomalasia primer (penyakit kongenital) dan sekunder (penyakit didapat). 


\section{Manifestasi Klinis}

Pada anamnesis didapat riwayat stridor ekspirasi yang biasanya timbul saat usia 4-8 minggu. Sebelum periode ini, gangguan pada aliran udara tersebut tampak sebagai suara napas abnormal. Stridor ekspirasi meningkat saat aktivitas, posisi supinasi, menangis, infeksi pernapasan, dan menurun saat istirahat. Kadang ditemukan kesulitan minum, suara parau dan afonia. Perlu pula dicari adanya riwayat intubasi berkepanjangan, trakeostomi, trauma

Tabel 1. Penyakit-penyakit yang berhubungan dengan trakeomalasia

Primer (kongenital)

- bayi normal (idiopatik)

- bayi kurang bulan

- kolaps pulsatil dengan arteri inominata normal

- abnormalitas kartilago kongenital (diskondroplasia/ kondromalasia/kondrodisplasia, polikondritis, sindrom Ehlers-Danlos)

- sindrom kongenital yang berhubungan dengan trakeomalasia [mukopolisakaridosis (sindrom Hurler, sindrom Hunter), sindrom CHARGE, anomali VATER, trisomi 9, trisomi 21, atelosteogenesis tipe 1, sindrom Antley-Bixler, delesi 11p13, delesi 22q11, translokasi 1822, sindrom Hallermann-Streiff, sindrom WilliamsCampbell, displasia Camptomelic, sindrom Pierre-Robin]

- anomali kongenital yang berhubungan dengan trakeomalasia (fistula trakeoesofagus, EA dengan atau tanpa celah laring, displasia bronkopulmonari)

Sekunder (didapat)

- Intubasi berkepanjangan

- Trakeostomi

- Trakeobronkitis berat

- Disebabkan karena tekanan [pembuluh darah (arkus aorta ganda, abnormalitas arteri inominata, anomali arteri pulmonalis kiri, arkus aorta kanan, subklavia kanan aberan, vena pulmonalis melebar), jantung (hipertrofi atrium kiri, atrium kiri membesar), tulang rangka (skoliosis, pektus ekskavatum), tumor atau kista (teratoma, higroma kistik, hemangioma, kista bronkogenik, kista enterogenik, timoma, pembesaran timus, goiter, malformasi limfe, limfoma, neuroblastoma), infeksi (abses), pasca trauma]

Sumber: Carden KA, Boiselle PM, Waltz DA, Ernst A. Tracheomalacia and tracheobronchomalacia in children and adults an in-depth review. Chest 2005; 127:984-1005. dada, trakeobronkitis berulang, penyakit kartilago (polikondritis relaps), dan reseksi paru sebagai faktor penyebab trakeomalasia didapat. ${ }^{2,3}$ Riwayat breath holding dapat terjadi; patogenesis terjadinya belum diketahui. ${ }^{10}$ Pada pemeriksaan fisik, bayi dengan kelainan ini tampak dalam kondisi baik meski dengan mengi kronik. Tanda vital, termasuk laju respirasi dan saturasi oksigen normal. Saat inspirasi terjadi retraksi supraklavikula dan interkosta. Kasus trakeomalasia kronik terutama usia muda mengalami deformitas dada. Pada auskultasi, suara inspirasi normal tapi suara ekspirasi abnormal. Suara mengi yang terjadi selama fase ekspirasi tersebut merata pada seluruh lapang paru. Ini merupakan suara ekspirasi kasar yang digambarkan sebagai stridor ekspirasi. Jarang terlihat tanda-tanda gangguan pertumbuhan. ${ }^{2,3}$ Pada trakeomalasia ekstratoraks akan ditemukan stridor inspirasi. Batuk terjadi akibat posisi dinding anterior-posterior trakea yang berdekatan sehingga menyebabkan getaran dan iritasi berulang jalan napas. ${ }^{1}$ Trakeomalasia kongenital mungkin berhubungan dengan berbagai macam anomali kongenital. ${ }^{2,9}$ Pada Tabel 1 dapat dilihat penyakit-penyakit yang berhubungan dengan trakeomalasia.

\section{Diagnosis}

Diagnosis trakeomalasia ditegakkan berdasarkan anamnesis, pemeriksaan fisik, dan pemeriksaan pencitraan. Pada pemeriksaan foto dada tampak gambaran hiperinflasi, penyempitan lumen trakea yang berlebihan selama ekspirasi, atau tampak adanya anomali vaskular misalnya arkus aorta ganda. Cinefluoroscopy dengan kontras pada esofagus saat respirasi biasa dan batuk, merupakan suatu bukti yang mendukung diagnosis. Saat batuk, lebih dari setengah sampai seluruh lumen trakea kolaps.

Kolaps jalan napas dinamis tampak terlihat baik dengan menggunakan ultrafast CT scan. ${ }^{2}$ Gambaran CT scan yang didapatkan saat akhir ekspirasi dan selama pernapasan dinamis merupakan suatu metoda yang akurat dan tidak invasif dalam mendiagnosis trakeomalasia, namun pada beberapa keadaan $M R I$ lebih dipilih pada anak. $M R I$ tidak menggunakan radiasi pengion, suatu pencitraan yang ideal untuk mendeteksi cincin atau jeratan paratrakea yang menekan jalan napas, dan tidak memerlukan pemakaian bahan kontras iodin, sehingga ini 
merupakan pilihan pada pasien dengan kontraindikasi penggunaan bahan kontras iodin, untuk melihat massa di daerah paratrakea. ${ }^{11}$

Pemeriksaan lain yang diperlukan antara lain pemeriksaan fungsi paru dan kurva volume aliran, yang lebih banyak dikerjakan pada orang dewasa. Pada pemeriksaan ini didapatkan kurva inspirasi normal tetapi dengan ekspirasi yang terpotong-potong. Diagnosis definitif ditegakkan melalui anamnesis dan endoskopi yang baik. Jalan napas divisualisasikan langsung selama pernapasan spontan dengan menggunakan laringoskop ventilasi dan bronkonskopi teleskop. Pada bronkoskopi fleksibel didapatkan hilangnya bentuk semisirkular normal bentuk lumen trakea, bentukan seperti balon ke arah depan dinding membran posterior, dan penyempitan anteroposterior lumen trakea yang dikenal sebagai triad klasik. ${ }^{2}$

\section{Diagnosis Banding}

Diagnosis banding trakeomalasia meliputi asma, bronkiolitis, kista bronkogenik, kistik fibrosis, dan benda asing pada jalan napas. ${ }^{1-3}$ Gejala asma mirip dengan trakeomalasia, untuk membedakannya dapat dilakukan dengan anamnesis yang baik, adanya faktor atopi, dan dengan pemberian $ß-2$ agonis menunjukkan perbaikan pada asma sementara pada trakeomalasia menunjukkan perburukan. ${ }^{3,12}$ Bronkiolitis merupakan suatu infeksi saluran napas bawah yang umumnya disebabkan oleh virus yang diawali infeksi traktus respiratorius atas dan demam. ${ }^{13}$

Kista bronkogenik berasal dari suatu penonjolan abnormal divertikulum trakea foregut, yang umumnya ditemukan dekat garis tengah (trakea, esofagus, karina). Gejala muncul apabila terdapat infeksi atau kista membesar sehingga menimbulkan tanda penekanan jalan napas. Pada pemeriksaan roentgen dada dapat terlihat kista, yang mungkin terdapat batas udaracairan. ${ }^{14}$ Kistik fibrosis merupakan suatu kelainan multisistem dengan gejala utama obstruksi dan infeksi kronis jalan napas dan maldigesti. Kelainan ini dapat dibedakan dengan trakeomalasia dengan melihat manifestasi klinis lainnya dari kistik fibrosis yang multisistem ini dan pemeriksaan uji keringat. ${ }^{3,15}$

Benda asing pada jalan napas dibedakan dari trakeomalasia dengan adanya awitan yang tiba-tiba, riwayat aspirasi benda asing, pemeriksaan laringoskopi langsung (benda asing di laring) atau bronkoskopi (benda asing di trakea), pemeriksaan foto dada, dan CT scan untuk mengetahui kemungkinan benda asing atau lesi lainnya pada jalan napas. ${ }^{3,16}$

\section{Tata laksana}

Sebagian besar anak dengan trakeomalasia tidak memerlukan intervensi. Kartilago trakea akan menguat dan menjadi lebih kaku seiring dengan pertumbuhan dan perkembangan anak. Pada trakeomalasia anak dengan gejala ringan-sedang, gejala klinis seringkali mereda saat usia 1-2 tahun, sehingga untuk kasus ringan dipilih terapi konservatif. ${ }^{1}$

Tatalaksana konservatif terdiri dari pemberian udara yang dilembabkan, fisioterapi dada, pemberian minum dan makan yang perlahan-lahan dan hati-hati, serta pengobatan dengan antibiotika jika terdapat infeksi. ${ }^{1,2}$ Penggunaan CPAP (Continuous positive airway pressure) direkomendasikan untuk pasien dengan distres pernapasan dan berguna untuk pasien yang memerlukan intervensi dalam jangka waktu pendek karena kelainan ini akan sembuh sendiri. ${ }^{2}$ Penggunaan CPAP meningkatkan aliran udara ekspirasi maksimal dari kapasitas residu fungsional secara sekunder karena peningkatan volume paru pada bayi sehat dan bayi dengan trakeomalasia. ${ }^{17}$

Penggunaan bronkodilator akan memperburuk trakeomalasia. Tegangan otot polos jalan napas menolong untuk menegakkan jalan napas, sehingga dengan pemberian ß-2 agonis akan merelaksasi otot tersebut dan menyebabkan semakin kolapsnya jalan napas. ${ }^{3}$ Fisioterapi berguna untuk mengatasi kesulitan bernapas akibat sekresi yang tertahan dalam saluran napas. Jika terdapat refluks gastroesofagus maka penderita diberikan makanan yang lebih kental, posisi kepala lebih tinggi dari badan, dan pemberian obat prokinetik (cisaprid, metoklopramid), pada kasus yang berat diberikan pula antagonis reseptor $\mathrm{H}-2$ (cimetidin, ranitidin). ${ }^{3,9}$ Kortikosteroid sistemik digunakan pada bayi yang mengalami peningkatan gejala selama infeksi saluran napas. ${ }^{3}$

Terapi bedah hanya direkomendasikan pada gejala berat dan terjadi kegagalan terapi konservatif, gangguan pertumbuhan dan perkembangan, pneumonia atau apnea berulang, obstruksi respirasi intermiten, dan obstruksi jalan napas yang memerlukan dukungan jalan napas kronik. ${ }^{1-3}$ Terapi bedah mencakup koreksi penyakit dasarnya, misalnya cincin vaskular, trakeostomi, dan 
aortopexy. Trakeostomi memberikan internalstenting pada trakea bayi tersebut, dengan berjalannya waktu dan pertumbuhan terjadi, maka obstruksi jalan napas menghilang, kanula tersebut dapat diangkat. ${ }^{2,3}$ Komplikasi pascaoperasi penggunaan internal stenting pada trakea ini adalah perdarahan trakea yang dapat menyebabkan kematian, ${ }^{18}$ sampai saat ini belum ada hasil operasi yang sempurna untuk kasus yang berat meski aortopexy dikatakan memiliki morbiditas yang lebih kecil dibandingkan dengan trakeostomi. ${ }^{19}$

Pada suatu penelitian pendahuluan mengenai penggunaan protein-2 morfogenetik tulang lepas lambat spon gelatin yang diletakkan pada irisan tengah cincin kartilago trakea leher anjing, didapatkan suatu regenerasi kartilago dan bentukan tulang baru yang menjembatani bagian kartilago yang terputus pada trakeomalasia. Penemuan ini mungkin merupakan suatu penemuan yang akan berguna untuk penatalaksanaan trakeomalasia di masa mendatang yang masih memerlukan penelitian lebih lanjut. ${ }^{20}$

\section{Prognosis}

Sebagian besar trakeomalasia primer akan membaik pada usia 6-12 bulan, dan biasanya menghilang secara spontan pada usia 18-24 bulan karena terjadi perbaikan integritas struktural trakea secara bertahap, ${ }^{1,2,9}$ namun pada pasien trakeomalasia dengan kelainan jaringan penunjang atau penyakit dengan sindrom kongenital, trakeomalasia yang diakibatkan oleh kelainan tersebut akan tetap ada dan bahkan dapat berakibat fatal.

Pada trakeomalasia sekunder yang disebabkan karena kompresi struktur abnormal paratrakea, walaupun telah dilakukan koreksi bedah terhadap struktur abnormal tersebut, kelemahan dan kolapsnya dinding trakea tetap ada dan memerlukan evaluasi serta penatalaksanaan tambahan lebih lanjut.

Pada trakeomalasia yang mengancam jiwa, angka kematiannya cukup tinggi yaitu sebesar $80 \% .{ }^{1}$ Gabungan antara diagnosis trakeomalasia yang ditegakkan dengan cinetracheobronchography dengan kontras dan pemakaian ventilator lebih dari 21 hari dapat digunakan untuk meramalkan kematian dengan nilai prediksi positif sebesar $100 \% .^{21}$

Trakeostomi dilakukan untuk mempertahankan jalan napas sampai terjadi maturasi dari kartilago secara alamiah. Tetapi hal ini menimbulkan komplikasi yang serius pada anak. Aortopexy merupakan pilihan terapi yang lebih aman dan memiliki morbiditas jangka panjang yang lebih kecil dibanding trakeostomi dengan keberhasilan sekitar 75\% pasien kegagalan terapi aortopexy hanya terjadi pada pasien dengan kelainan trakea difus atau proksimal. ${ }^{2}$

\section{Kesimpulan}

Trakeomalasia merupakan suatu keadaan kelemahan trakea dengan berbagai penyebab, dapat terjadi secara primer maupun sekunder. Diagnosis dapat ditegakkan melalui anamnesis, pemeriksaan fisik dan pencitraan. Penatalaksanaannya meliputi konservatif atau tindakan bedah. Tindakan pembedahan dilakukan jika mengalami kegagalan terapi konservatif. Penggunaan protein-2 morfogenik tulang lepas lambat dalam penatalaksanaan trakeomalasia masih memerlukan penelitian lebih lanjut. Pada sebagian besar bayi dengan trakeomalasia gejalanya akan menghilang pada usia 1824 bulan.

\section{Daftar Pustaka}

1. Carden KA, Boiselle PM, Waltz DA, Ernst A. Tracheomalacia and tracheobronchomalacia in children and adults an in-depth review. Chest 2005; 127:9841005.

2. Sharma S. Tracheomalacia. Emedicine World Medical Library 2004 November [Diakses 9 Maret 2005]. Didapat dari: URL: http://www.emedicine.com/html.

3. Bye MR. Tracheomalacia. Emedicine World Medical Library 2004 Desember [Diakses 9 Maret 2005]. Didapat dari: URL: http://www.emedicine.com/html.

4. Kang FC, Tsai YC, Jiang CY, Chen HP, Chang CL. Acquired tracheomalaci a case report. Acta Anaesthesiol Sin 1996; 34:239-42.

5. Callahan CW. Primary tracheomalacia and gastroesophageal reflux in infants with cough. Clin Pediatr 1998; 37:725-31.

6. Jacobs IN, Wetmore RF, Tom LW. Tracheobronchomalacia in children. Arch Otolaryngol Head Neck Surg 1994; 120:154-8.

7. Levillain S, Roman S, Nicollas R, Triglia JM. Tracheomalacia and tracheal dyskinesias. Arch Pediatr 2001; 8:757-62.

8. Beasley SW, Qi BQ. Understanding tracheomalacia. J Paediatr Child Health 1998; 34:209-10. 
9. Bibi H, Khvolis E, Shoseyov D. The prevalence of gastroesophageal reflux in children with tracheomalacia and laryngomalacia. Chest 2001; 119:409-13.

10. Griffiths H, Doull I, Williams RG, Marnane C. Tracheomalacia and breath holding: a case report. Arch Dis Child 2000; 83:340-1.

11. Boiselle PM, Ernst A. Recent advances in central airway imaging. Chest 2002; 121:1651-60.

12. Rahajoe N, Supriyatno B, Setyanto DB. Pedoman nasional asma anak. Jakarta: UKK Pulmonologi PP IDAI; 2004. h. 1-4.

13. Orenstein DM. Bronchiolitis. Dalam: Behrman RE, Kliegman RM, Arvin AM, penyunting. Nelson textbook of pediatrics. Edisi ke-17. Philadephia: W.B. Saunders Company; 2004. h. 1211-3.

14. Stern RC. Congenital anomalies. Dalam: Behrman RE, Kliegman RM, Arvin AM, penyunting. Nelson textbook of pediatrics. Edisi ke-17. Philadephia: W.B. Saunders Company; 2004. h. 1198-201.

15. Boat TF. Cystic fibrosis. Dalam: Behrman RE, Kliegman RM, Arvin AM, penyunting. Nelson textbook of pediatrics. Edisi ke-17. Philadephia: W.B. Saunders Company; 2004. h. 1239-51.
16. Orenstein D. Foreign bodies in the larynx, trachea, and bronchi. Dalam: Behrman RE, Kliegman RM, Arvin AM, penyunting. Nelson textbook of pediatrics. Edisi ke-17. Philadephia: W.B. Saunders Company; 2004. h. 1205-8.

17. Davis S, Jones M, Kisling J, Angelicchio C, Tepper RS. Effect of continous positive airway pressure on forced expiratory flows in infants with tracheomalacia. Am J Respir Crit Care Med 1998; 158:148-52.

18. Geller KA, Wells WJ, Koempel JA, John MAS. Use of the Palmaz stent in the treatment of severe tracheomalacia. Ann Otol Rhino Laryngol 2004; 113:641-7.

19. Greenholz SK, Karrer FM, Lilly JR. Contemporary surgery of tracheomalacia. J Pediatr Surg 1986; 21:511-4.

20. Okamoto T, Yamamoto Y, Gotoh M. Cartilage regeneration using slow release of bone morphogenetic protein-2 from a gelatin sponge to treat experimental canine tracheomalacia: a preliminary report. ASAIO 2003; 49:63-9.

21. Burden RJ, Shann F, Butt W, Ditchfield M. Tracheobronchial malacia and stenosis in children in intensive care: bronchograms help to predict outcome. Thorax 1999; 54:511-7. 